ISSN 0103-5150

Fisioter. Mov., Curitiba, v. 29, n. 1, p. 79-86, Jan./Mar. 2016

Licenciado sob uma Licença Creative Commons

DOI: http://dx.doi.org.10.1590/0103-5150.029.001.A008

(c) (9)

\title{
Relationship of muscle strength with activities of daily living and quality of life in individuals with chronic obstructive pulmonary disease
}

\author{
Relação das forças musculares com as atividades \\ da vida diária e qualidade de vida em indivíduos \\ com doença pulmonar obstrutiva crônica
}

\section{Gualberto Ruas $^{[a]}$, Wilbert Esteban Cárdenas Urquizo ${ }^{[a]}$, George Kemil Abdalla ${ }^{[b]}$, Dayana Pousa Siqueira Abrahão ${ }^{[b]}$, Fabrizio Antonio Gomide Cardoso ${ }^{[a]}$, Patrícia Sena Pinheiro ${ }^{[a]}$, Mauricio Jamami ${ }^{[c] *}$}

[a] Universidade Federal do Triângulo Mineiro (UFTM), Uberaba, MG, Brazil

[b] Faculdade de Talentos Humanos (FACTHUS), Uberaba, MG, Brazil

[c] Universidade Federal de São Carlos (UFSCar), São Carlos, SP, Brazil

\section{Abstract}

Introduction: Few activities of daily living (ADLs) in chronic obstructive pulmonary disease (COPD) are tolerated because they are associated with ventilatory and metabolic changes. Simply lifting the upper limb muscle requires changes, resulting in thoracic abdominal asynchrony, increased dyspnea, and can interfere

* GR: PhD, e-mail: gualbertoruas@yahoo.com.br WECU: grad, e-mail: wilcarur@hotmail.com GKA: PhD, e-mail:gkabdalla@facthus.edu.br DPSA: MSc, e-mail: dpsiqueira@facthus.edu.br FAGC: PhD, e-mail: fabriziokaren@gmail.com PSP: MSc student, e-mail: paty.fisioterapia10@hotmail.com MJ: PhD, e-mail: jamami@power.ufscar.br 
with quality of life (QoL). Objective: to relate the muscle strength of the shoulder girdle, trunk and hand grip with the degree of dyspnea in ADLs and secondarily correlate them with QoL in individuals with chronic obstructive pulmonary disease. Materials and Methods: Nine male subjects with chronic obstructive pulmonary disease III and IV (COPDG) and nine healthy, sedentary male individuals - control group (CG) were evaluated. All patients underwent the following evaluations: Pulmonary function, muscle strength of shoulder girdle, trunk and hand grip, and questionnaires. Results: In the intergroup analysis found that the spirometric variables of the COPDG were significantly lower compared to the CG. Intragroup analysis for measures of muscle strength, found significant difference for shoulder girdle, trunk and hand grip between both groups (COPDG) with lower mean (CG). Only the shoulder girdle had a positive correlation with ADL's and QoL. Conclusion: COPDG individuals, in addition to having pulmonary compromise, showed a significant decrease in muscle strength of the shoulder girdle, trunk and hand grip when compared to the CG. Only the shoulder girdle strength was positively correlated with the level of dyspnea in ADL's in QoL. Thus, pulmonary rehabilitation is an important tool for strengthening these muscles, possibly providing a positive impact on the degree of dyspnea during ADLs and reflecting on QoL.

Keywords: COPD. Muscle strength. ADL's. QoL. Shoulder girdle.

\section{Resumo}

Introdução: As atividades da vida diária (AVD's) na doença pulmonar obstrutiva crônica(DPOC) são poucas toleradas pelo fato de estarem associadas a alterações ventilatórias e metabólicas. A simples elevação dos membros superiores altera o recrutamento muscular, resultando em assincronia toracoabdominal, aumento da dispneia, podendo interferir na sua qualidade de vida (QV).Objetivo: relacionar as forças musculares da cintura escapular(CE), tronco(T) e preensão palmar(PP) com os graus de dispneia nas AVD's e secundariamente correlacioná-las com a QV em indivíduos com DPOC. Materiais e Métodos: Foram avaliados 09 indivíduos com DPOC (III e IV) do sexo masculino - grupo DPOC (GDPOC) e 09 indivíduos saudáveis sedentários - grupo controle (GC). Todos foram submetidos às seguintes avaliações: prova de função pulmonar, forças musculares da CE, T, PP e questionários. Resultados: Na análise intergrupos constatou que as variáveis espirométricas do GDPOC foram significativamente menores comparados aos do GC. Na análise intragrupo, para as medidas das forças musculares, observou-se diferença significativa para PP, Te CE entre ambos os grupos (GDPOC com média menor que GC). Somente na força da CE houve correlação positiva com as AVD's e QQV. Conclusão: Concluímos que indivíduos do GDPOC possuem, além do comprometimento pulmonar, apresentam diminuição significativa da força muscular da CE, T e PP quando comparado ao GC. Somente na força da CE houve correlação positiva com os graus de dispneia nas AVD's e na QV. Sendo assim, a reabilitação pulmonar é um importante instrumento para o fortalecimento dessa musculatura proporcionando possivelmente um impacto positivo nos graus de dispneia durante as AVD's e refletindo $n a Q V$.

Palavras-chave: DPOC. Força muscular. Cintura escapular. Qualidade de vida. AVD's.

\section{Introduction}

Chronic obstructive pulmonary disease (COPD) is defined as a preventable and treatable, but not fully reversible, respiratory disease characterized by chronic airflow obstruction. The airway obstruction is usually progressive and is associated with abnormal pulmonary inflammatory response against chronic particles or toxic gases, especially cigarette smoke (1). It affects between $5-15 \%$ of the adult population
(2). Although the lungs are affected, diverse systemic manifestations are found.

The changes are airway inflammation and destruction of the lung parenchyma. These modifications contribute to the main disease marker, which is airflow limitation. However, the clinical picture and the impact on the general state of the patient's health are influenced by systemic manifestations, and reinforce the need for a multidimensional approach involving all components of the disease (3). 
Studies have shown that patients present weight loss, and a loss of lean body mass resulting in peripheral muscle dysfunction, decreased muscle strength, exercise tolerance, with a reduction in muscle strength proportional to the reduction in muscle mass $(4,5$, 6 ), in addition to respiratory muscle weakness (7).

Simple activities of daily living (ADLs) in COPD, requiring the use of the upper limbs and trunk, are poorly tolerated as they are associated with significant ventilatory and metabolic disorders $(8,9)$. The simple lifting of upper extremities affects ventilatory and postural muscle recruitment, resulting in thoracoabdominal asynchrony, an increased dyspnea sensation in a short period of time (10), stopping the exercise at lower loads (11), and may interfere with their quality of life (QoL) (12).

Muscle strength can be defined as the maximum amount of force that a muscle or muscle group can generate for a specific pattern of movement; it is considered an important physical capacity for physical conditioning not only for athletes, but also for non-athletic individuals (13). In this context, various forms of muscle strength assessment have been proposed, both mechanical as well as manual (14); among them, the dynamometers of shoulder girdle, trunk and hand grip.

Whereas there are no studies that have used the dynamometers of the shoulder girdle, trunk and hand grip in COPD related to the degree of dyspnea on ADLs and QoL, this study aimed to relate the muscle forces of the shoulder girdle, trunk and hand grip with the degree of dyspnea in ADLs, and secondarily to correlate them with the QoL in individuals with COPD.

\section{Material and methods}

\section{Casuistic}

Nine volunteers of the male - COPD group (COPDG) were assessed, with stage III and IV COPD, according to Gold, (15). In addition, for comparative parameters, nine healthy, sedentary volunteers who belonged to the control group (CG) were evaluated, as demonstrated in Table 1. The evaluations were performed on different days at the Maria da Glória Clinic, in the Pulmonology and Phthisiology of the Federal University of Triangulo Mineiro (UFTM).

Inclusion criteria were: forced expiratory volume in one second (FEV1) $<50 \%$ of expected, and forced expiratory volume ratio in one second by forced vital capacity (FEV1/FVC) $<70 \%$, verified by postbronchodilator spirometry (BDS); age less than 50 years; in stable clinical condition, without periods of exacerbation of the disease and without respiratory infections for at least one month before the initial evaluation; sedentary; no smokers or former smokers, receiving medical treatment; body mass index (BMI) $<30 \mathrm{~kg} / \mathrm{m}^{2}$.

Two sample volunteers were excluded, one of the COPDG and one of the CG group who had cardiovascular, neurological and/or osteoarticular diseases that prevented a safe performance of evaluations.

All volunteers who agreed to participate in the evaluations were informed about the research project characteristics, number: 18218, and could choose either to participate or not to do so, without any prejudice or onus, signing an informed consent as required by Resolution 196/96 of the National Health Council. In this research no volunteers received any financial aid.

\section{Experimental Procedure}

The evaluations were performed on different days, and at random, by two trained examiners. The volunteers underwent the following ratings: pulmonary function, muscle strength of the shoulder girdle, trunk and hand grip, and they answered four questionnaires as part of an interview (level of dyspnea, physical activity level, degree of dyspnea in ADLs, and QOL) .

Pulmonary function test (spirometry).

Spirometry is an important evaluation parameter for the classification of patients according to the severity of lung obstruction. It was performed using a spirometer of the Vitalograph ${ }^{\circledR}$ brand, model 8600.

The equipment was calibrated periodically and tests were performed only by a trained and qualified examiner with instructions and standardized voice command, as per the regulations recommended by the First Brazilian Consensus on Spirometry (16).

Volunteers remained seated during tests, with their feet resting on the floor, with their back against the chair, and using a nasal clip (17).

The test was a compound of a slow vital capacity maneuver (SVC), forced vital capacity (FVC); for each maneuver at least three trials were performed, with the best trial accepted and recorded by the machine. 
The spirometric results were expressed in graduated volume-time graphs, in liters and seconds, with vital capacity values, FVC, FEV1 and peak expiratory flow obtained.

According to Pereira et. al., the values of this research were expressed in percentage of the predicted value, according to the age, height, gender, race and weight of each individual (16).

\section{Hand grip strength}

For hand grip evaluation, a grip dynamometer was used, of the Crown ${ }^{\circledR}$ brand, with a capacity of 50 kilogram-force (kgf). The volunteers were placed in the sitting position without support for the arms, with hips and knees flexed to $90^{\circ}$, and their feet flat on the floor. The shoulders were adducted and in neutral position for rotation, elbow in a 90 degree flexion, forearm and wrist in a neutral position (18).

After positioning, volunteers performed three maneuvers of maximum gripping, with the dominant hand; to avoid muscle fatigue there was one minute of rest between attempts. The results were expressed as kgf, with a mean of the three measurements.

\section{Trunk Strength}

The trunk force was measured by lumbar dynamometry. Lumbar dynamometry was performed using a Crown ${ }^{\circledR}$ brand unit with a capacity of 200 kgf. To perform the lumbar traction, volunteers were positioned standing on the dynamometer platform with the knees completely extended and the trunk flexed slightly forward, forming an angle of 120 degrees. The feet and head followed the extension of the trunk, staring forward. Volunteers were instructed to position themselves with elbows extended, holding the bar with both hands apart, at a distance equal to the bitrocanteric diameter. After positioning, they were guided to apply the greatest strength in the muscles of the lower back, trying to avoid to the maximum the use of the muscles of the upper and lower limbs.

Three attempts of maximum strength were conducted with the contractions maintained between 3 - 5 seconds, with an interval of two minutes between trials (19).
Shoulder girdle strengthening

Scapular strength was measured through a scapular dynamometer. To measure the scapular strength, the scapular dynamometer with a capacity of $50 \mathrm{kgf}$, from the Crown ${ }^{\circledR}$ brand, was used. Individuals were instructed to position themselves in a standing position, increasing their support base with their hips slightly abducted. Individuals held the dynamometer with both hands, at the height of the sternum, with flexed elbows and shoulders abducted and internally rotated. After positioning, they were instructed to pull the arms to perform a shoulder abduction, maintaining the contraction for 3 to 5 seconds. Three attempts were performed, with an interval of one minute between them. The tests began with the pointer at zero and with arms supported.

Volunteers were monitored for heart rate, blood pressure and oxygen saturation during the tests. In case of any complications, a pulmonologist physician would be requested.

Level of dyspnea in activities of daily living (ADLs)

The London Chest Activity of Daily Living scale (LCADL) (20) was used with the domains of personal care, domestic activities, physical activities, leisure activities, and total score. The higher the score, the higher the dyspnea limitation to perform the ADLs. The Modified Score Medical Research Council scale (MRC) (21) to establish the level of dyspnea in daily life was also used. This five point scale is based on different activities that may result in the sensation of dyspnea. The higher the score, the more disability was present.

\section{Quality of Life (QoL) - Saint George's Respiratory Questionnaire (SGRQ)}

The Saint George's Respiratory Questionnaire (SGRQ) was used to measure QoL, being specific for individuals with this disease, and because it is validated in the Portuguese language. The SGRQ is divided into three domains: symptoms, activity and psychosocial impact of the disease. The score was calculated for each domain, and the total score was the sum of the scores of the three domains (22); the higher the score, the worse the quality of life. 
Physical Activity Level

The International Physical Activity Questionnaire Short Form (IPAQ-SF) has four questions to assess the level of physical activity, and was applied,by two trained examiners to individuals of both groups (COPDG and CG).

\section{Statistical analysis}

The Shapiro-Wilk test was conducted in order to verify the normality of the data distribution. Descriptive statistics were applied to characterize the sample, and the data were expressed as mean \pm standard deviation. For intergroup analysis, the independent Student t-test was used and, for intragroup analysis, the paired Student t-test was used, in addition to the Pearson correlation coefficient. The Statistical Package for the Social Sciences (SPSS) for Windows, version 13.0, was the statistical program used. The accepted significance level was $5 \%$.

\section{Results}

Demographic, anthropometric, spirometric and Saturation of Peripheral Oxygen $\left(\mathrm{SpO}_{2}\right)$ of the COPDG and CG individuals are shown in Table 1. In the intergroup analysis, the COPDG spirometric variables were significantly lower when compared to CG, indicating obstruction of the airways. The level of physical activity, verified by time of walking (in minutes), moderate and intense activities, and of all activities performed in the week (Table 2), did not show any difference between groups.

Table 1 - Characteristics of the studied subjects

\begin{tabular}{lcc}
\hline \multicolumn{1}{c}{ Variables } & $\begin{array}{c}\text { COPDG }(\mathbf{n}=\mathbf{9}) \\
\text { Median (interquartile) }\end{array}$ & $\begin{array}{c}\text { CG }(\mathbf{n}=\mathbf{9}) \\
\text { Median (interquartile) }\end{array}$ \\
\hline Sex & 9 man & 9 man \\
Age & $77 \pm 12(60-88)$ & $68 \pm 6(61-78)$ \\
Height $(\mathrm{cm})$ & $167 \pm 10(163.7-170.3)$ & $175 \pm 5(168.7-177.9)$ \\
Weight $(\mathrm{Kg})$ & $71 \pm 5(61.8-78.1)$ & $72 \pm 5(65.4-85.9)$ \\
BMI $\left(\mathrm{kg} / \mathrm{m}^{2}\right)$ & $24 \pm 2(21.6-26.9)$ & $25 \pm 6(21.7-27.9)$ \\
FEV1\% (L) & $46.6 \pm 4(37.3-64)$ & $108.6 \pm 5(97.8-116.9)^{\star}$ \\
FEV1 (L) & $1.25 \pm 0.2(0.9-1.7)$ & $3.36 \pm 1.1(3.1-3.7)^{\star}$ \\
FVC (\%) & $71.4 \pm 2(61.4-74)$ & $116.6 \pm 15(106.8-127.2)^{\star}$ \\
FVC (L) & $2.1 \pm 0.2(1.6-2.5)$ & $4.28 \pm 0.8(3.9-5.1)^{\star}$ \\
FEV1/FVC \% & $65.2 \pm 12(56.4-72.8)$ & $96.2 \pm 22(88.8-99.6)^{\star}$ \\
Baseline Sp02 (\%) & $93 \pm 12(92-95)$ & $97 \pm 6(95-98)$ \\
\hline
\end{tabular}

Note: COPDG: COPD group; CG: control group; cm: centimeter; kg: kilogram; Kg / m²: kilograms per meter squared; L: liter; \%: Percentage; BMI $=$ body mass index; $\mathrm{FEV} 1=$ forced expiratory volume in one second; $\mathrm{FVC}=$ forced vital capacity; $\mathrm{Sp02}=$ Saturation of peripheral oxygen.

* Statistically significant difference (independent t-test) $(p<0.05)$ intergroup.

Table 2 - Physical activity in COPDG and CG

\begin{tabular}{lcc}
\hline & $\begin{array}{c}\text { COPDG } \\
(\mathbf{n}=\mathbf{0 9})\end{array}$ & $\begin{array}{c}\text { CG } \\
(\mathbf{n}=\mathbf{0 9})\end{array}$ \\
\hline Weekly walking time $(\mathbf{m i n})$ & $40(0-100)$ & $100(20-150)$ \\
Weekly moderate walking time $(\mathbf{m i n})$ & $30(0-120)$ & $90(30-180)$ \\
Weekly intense walking time $(\mathbf{m i n})$ & $60(0-180)$ & $60(30-180)$ \\
Total weekly walking time $(\mathbf{m i n})$ & $225(90-420)$ & $310(180-590)$ \\
\hline
\end{tabular}


Muscle strength: Shoulder Girdle, Trunk and Hand Grip

The measurement of muscle strength in intragroup analysis, did not show significant difference in the shoulder girdle, trunk and hand grip between groups, but the COPDG had a lower mean when compared to CG (Table 3).

Muscle strength correlation with scores of

Dyspnea Levels in ADLs, and QoL and the MRC

Only the shoulder girdle strength was positively correlated with the level of dyspnea in ADLs and QoL (Table 4).

Table 3 - Mean and standard deviation of muscle strength of hand grip, trunk and shoulder girdle of subjects studied

\begin{tabular}{lcc}
\hline Variables & $\begin{array}{c}\text { COPDG } \\
(\mathbf{n}=\mathbf{0 9}) \\
\text { Median } \\
\text { (interquartile) }\end{array}$ & $\begin{array}{c}\text { CG } \\
(\mathbf{n}=\mathbf{0 9}) \\
\text { Median } \\
\text { interquartile) }\end{array}$ \\
\hline $\begin{array}{l}\text { Hand grip } \\
\text { (Kg/f) }\end{array}$ & $29 \pm 8(17-45)$ & $40 \pm 7(35-47)^{*}$ \\
$\begin{array}{l}\text { Trunk (Kg/f) } \\
\text { Shoulder } \\
\text { girdle (Kg/f) }\end{array}$ & $54 \pm 2(28-71)$ & $84 \pm 18(60-110)^{*}$ \\
\hline
\end{tabular}

Note: COPDG: COPD group; CG: control group; Kg/f: kilogram force; *: Statistically significant difference (paired t-test) $(p<0.05)$ intragroups.

\section{Discussion}

The spirometric intergroup analysis of variables in the COPDG were significantly lower when compared to the CG, characterizing airway obstruction. In addition, the level of physical activity, verified by time (in minutes) of walking, of moderate and intense activities, and total activities performed in the week, showed no significant difference between groups.

A significant difference was found for shoulder girdle, trunk and hand grip between the groups in the intragroup analysis for muscle strength measures, and the COPDG had a lower average when compared to the CG.

Musculoskeletal strength in COPD has been the subject of research as one of the systemic manifestations of this disease. Its connection with the patient's QoL and its impact on the performance of ADLs is discussed. Literature does not show studies associating the strength of shoulder girdle, hand grip and trunk to the level of dyspnea on ADLs and the impact on QoL, which justified this research. Through its results, the existence of a relationship between the strength of the shoulder girdle with the level of dyspnea on ADLs and QoL could be established.

This finding may be explained by the use of upper limb muscles in the shoulder girdle test, which in turn belongs to the group of accessory muscles used for respiration.

According to Baarends et. al., (23), activities such as hair combing, brushing teeth or shaving involve shoulder muscles without support and upper limbs, and many of these muscles are still part of the accessory muscles of respiration.

Table 4 - Correlation of muscle strength versus ADLs, QoL, MRC

\begin{tabular}{|c|c|c|c|}
\hline \multirow[t]{2}{*}{ Variables } & \multicolumn{3}{|c|}{$\begin{array}{c}\text { COPDG } \\
\text { Median (interquartile) }\end{array}$} \\
\hline & AVDs & QoL & MRC \\
\hline Hand grip (Kg/f) & $r:-0.49(p<0.2)^{\mathrm{NS}}$ & $r:-0.35(p<0.3)^{\text {Ns }}$ & $r:-0.33(p<0.4)^{N S}$ \\
\hline Trunk (Kg/f) & $r:-0.58(p<0.3)$ NS & NS $r:-0.47(p<0.4)$ NS & $r:-0.33(p<0.4)^{N s}$ \\
\hline Shoulder girdle $(\mathrm{Kg} / \mathrm{f})$ & $r: 0.77(p<0.04)^{*}$ & $r: 0.6(p<0.04)^{*}$ & $r:-0.41(p<0.4)^{N S}$ \\
\hline
\end{tabular}

Note: COPDG: COPD group; Kg/f: kg force; ADLs: activities of daily living; QoL: questionnaire of quality of life; MRC: Medical Research Council (MRC) dyspnea scale; NS: not significant; *: Significant; $r$ : Pearson correlation with significance level of $p<0.05$. 
Criner and Celli (11) realized that breathing becomes ineffective in patients with COPD during activities involving upper limbs, as accessory muscles of breathing are recruited to stabilize the shoulder girdle. As a result, there is an overload of the diaphragm. In patients with COPD, dynamic hyperinflation (DH) generates the lowering of the diaphragm, losing its ability to contract, so chest muscles become more important to generate inspiratory pressure. Dynamic hyperinflation has been the subject of scientific research since it is an important aggravating factor in patients with COPD, favoring dyspnea and limiting their ability to perform physical exercise $(24,25)$, even the simplest activities of daily life routine, (26) (27) which has a negative effect on the patient's ADLs.

Patients with COPD in advanced stages have limited exercise tolerance, restricting their ADLs. $(28,29,30)$

The peripheral muscle atrophy and weakness, which are common in COPD, are associated with reduced physical capacity. $(28,29,30)$ This study demonstrates a significant difference between the COPDG and CG when comparing the musculoskeletal forces. Sedentary lifestyle of the patient with COPD, the manifestations of the disease itself, and the deficit in performing ADLs are among causes of strength difference between the two groups, which leads to a vicious circle of ADLs with physical inactivity and decreased peripheral muscle strength.

\section{Conclusions}

The conclusions of this study show that COPDG individuals have a significant decrease in muscle strength of the shoulder girdle, trunk and hand grip, in addition to pulmonary impairment, when compared to CG individuals. Only the strength of the shoulder girdle was positively correlated with the degree of dyspnea in ADLs and QoL.

\section{Study limitation}

Some limitations of this study are related to the small number of individuals who comprised both groups, and the absence of a COPD control group.

\section{References}

1. Dourado VZ, Tanni SE, Vale SA, Faganello MM, Sanchez FF, Godoy I. Manifestações sistêmicas na doença pulmonar obstrutiva crônica. J bras de pneumologia. 2006;32(2):161-71.

2. Menezes AMB, Jardim JR, Pérez-Padilla R, Camelier A, Rosa F, Nascimento O, Hallal PC, Team P. Prevalence of chronic obstructive pulmonary disease and associated factors: the PLATINO Study in São Paulo, Brazil. Cad Saúde Pública. 2005; 21(5):1565-73.

3. Wouters EF. Local and systemic inflammation in chronic obstructive pulmonary disease. Proc Am Thorac Soc. 2005;2(1):26-33.

4. Landbo C, Prescott E, Lange P, Vestbo J, Almdal TP. Prognostic value of nutritional status in chronic obstructive pulmonary disease. Am J Respir and Crit Care Med. 1999;160(6):1856-61.

5. Janssens JP, Rochat T, Frey JG. Health-related quality of life in patients under long-term oxygen therapy: a home-based descriptive study. Respiratory Medicine. 1997; 91:592-602.

6. White RJ, Rudkin ST, Ashley J. Outpatient pulmonary rehabilitation in severe chronic obstructive pulmonary disease. Journal of the Royal College Physicians of London. 1997;31:541-5.

7. Orozco-Levi M. Structure and function of the respiratory muscles in patients with COPD: impairment or adaptation? European Respiratory Journal. 2003;22(46):41-51.

8. Velloso M, Stella SG, Cendon S, Silva AC, Jardim JR. Metabolic and ventilatory parameters of four activities of daily living accomplished with arms in COPD patients. Chest. 2003;123(4):1047-53.

9. Jeng C, Chang W, Wai PM, Chou CL. Comparison of oxygen consumption in performing daily activities between patients with chronic obstructive pulmonary disease and a healthy population. Heart Lung. 2003;32(2):121-30.

10. Celli BR, Rassulo J, Make BJ. Dyssynchronous breathing during arm not leg exercise in patients with chronic airflow obstruction. N Engl J Med. 1986;314(23):1485-90. 
11. Criner GJ, Celli BR. Effect of unsupported arm exercise on ventilator muscle recruitment in patients with severe chronic airflow obstruction. Am Rev Respir Dis. 1988; 138: 856-6.

12. Sociedade Brasileira de Pneumologia e Tisiologia. I Consenso Brasileiro de Doença Pulmonar Obstrutiva Crônica (DPOC). J Bras Pneumol. 2000;26:1-52.

13. Komi PV. Strength and power in sport. London: Blackwell; 2003.

14. Reese NB. Testes de função muscular e sensorial. Rio de Janeiro: Guanabara Koogan; 2001.

15. GOLD - Global Strategy for the diagnosis, management and prevention of COPD: 2005 update. [Cited in 2010 set 20]. Available from: http://www.goldcopd.org.

16. Pereira CAC, Lemle A, Algranti E, Jansen JM, Valença LM, Nery LE, Mallozi M, Gerbase M, Dias RM, Zin WA. I Consenso Brasileiro sobre Espirometria. J Bras Pneumol. 1996;22(3):105-58.

17. Vilke GM, Chan TC, Neuman T, Clausen JL. Spirometry in normal subjects in sitting, prone, and supine positions. Respiratory Care. 2000;45(4):407-10.

18. Moreira D, Godoy JRP, Junior WS. Estudo sobre a realização da preensão palmar com utilização de dinamômetro: considerações anatômicas e cinesiológicas. Fisioterapia Brasil. 2001;2(5):295-300.

19. Pereira FG. Análise da correlação da força muscular com densidade mineral óssea em homens com idade igual ou superior a 60 anos, residentes em São Sebastião - DF [Dissertation]. Brasília: Faculdade de Ciências da Saúde, Universidade de Brasília; 2009.

20. Garrod R, Bestall JC, Paul EA, Wedzicha JA, Jones PW. Development and validation of a standardized measure of activity of daily living in patients with severe COPD: the London Chest Activity of Daily Living scale (LCADL). Respiratory Medicine. 2000;94(6):589-96.

21. Mahler D, Wells C. Evaluation of clinical methods for rating Dyspnea. Chest. 1998;93:580-86.
22. Camelier A, Rosa FW, Salmi OAN, Cardoso F, Jardim JR. Avaliação da qualidade de vida pelo Questionário do Hospital Saint George na Doença Respiratória em portadores de doença pulmonar obstrutiva crônica: validação de uma nova versão para o Brasil. Jornal Brasileiro de Pneumologia. 2006;32(2):114-22.

23. Baarends EM, Schols AM, Slebos DJ, Mostert R, Janssen PP, Wouters EF. Metabolic and ventilatory response pattern to arm elevation in patients with COPD and healthy age-matched subjects. European Respiratory Journal. 1995;8:1345-51.

24. O'donnell DE, Revill SM, Webb KA. Dynamic Hyperinflation and exercise intolerance in Chronic Obstructive Pulmonary Disease. Am J Respir Crit Care Med. 2001;164:770-7.

25. O'Donnell DE, Webb KA. Exertion breathlessness in patients with chronic airflow obstruction. Am Rev Respir Dis. 1993;148:1351-7.

26. Tangri S, Wolf CR. The breathing pattern in Chronic Obstructive lung Disease during the performance of some common daily activities. Chest. 1973;63:126-7.

27. Martinez F, Couser J, Celli B. Factors influencing ventilatory muscle recruitment in patients with chronic airflow obstruction. Am Rev Respir Dis. 1990;142:276-82.

28. Bernard S, Leblanc P, Whittom F, Carrier G, Jobin J, Belleau R, Maltais F. Peripheral Muscle Weakness in Patients with Chronic Obstructive Pulmonary Disease. Am J Respir Crit Care Med. 1998; 158:629-34.

29. Gosselink R, Troosters T, De Cramer M. Peripheral muscle weakness contributes to exercise limitation in COPD. Am J Respir Crit Care Med. 1996;153:976-80.

30. Hamilton AL, Killian KJ, Summers E. Muscle strength, symptom intensity and exercise capacity in patients with cardiorespiratory disorders. Am J Respir Crit Care Med. 1995;152:2021-31.

Recebido: 06/09/2013

Received: 09/06/2013

Aprovado: 26/06/2015

Approved: 06/26/2015 